\title{
Gerakan Penolakan Masyarakat Terhadap Pertambangan Pasir Besi Di Kecamatan Wera Kabupaten Bima Tahun 2018
}

\author{
Aidin \\ Sekolah Tinggi Keguruan dan Ilmu Pendidikan STKIP Al-Amin Dompu
}

\begin{abstract}
Abstrak. Gerakan Perlawanana Masyarakat Terhadap Pertambangan Pasir Besi Di Kecamatan Wera Kabupaten Bima”. Kabupaten Bima adalah salah satu Daerah yang kaya akan sumber daya alam, yang di mana sangat strategis dan luas apabila dikelola dan di perketat melalui aturan yang masif, maka kekayaan sumber daya alam adalah suatu aset yang harus dipergunakan sebagaimana mestinya, ada beberapa sektor yang bisa dikembangkan oleh Pemerintah Daerah, pertama pada sektor pertanian, sektor pertenakan, kelautan dan pertambangan dengan melihat potensi tersebut Pemerintah Daerah mengeluarkan Surat keputusan (SK) dengan nomor. 188/2010, kepada PT. Jagad Mahesa karya, yang bergerak dibidang pertambangan pasir besi di Kecamatan Wera Kabupaten Bima. Penelitian ini mengkaji permasalahannya yang diidentifikasi. Bagaimanakah model gerakan masyarakat terhadap pertambangan pasir di Kecamatan Wera Kabupaten Bima Untuk menjawab permasalahan di atas peneliti menggunakan teori Resistensi. Penelitian ini menggunakan penelitian kualitatif diskriptif dengan instrumen penelitian yang digunakan, observasi, wawancara dan dokumentasi. Informan penelitian ini adalah beberapa tokoh masyarakat, Pemerintah Daerah, Pihak Pertambangan. Faktor bagi masyarakat kehadiran pertambangan tidak akan mampu merubah cara hidup masyarakat, justru akan membuat masyarakat semakin miskin. Pertambangan pasir besi yang ada di Kecamatan Wera belum bisa diterima oleh masyarakat, karena disebabkan oleh pemahaman masyarakat terhadap pertambangan masih kurang.
\end{abstract}

\section{Kata kunci: Masyarakat,Pelaku usaha dan Pemerintah Daerah}

\section{PENDAHULUAN}

Kecamatan Wera merupakan bagian dari Kabupaten Bima yang terletak pesisir utara paling Timur dari Kabupaten Bima dan dengan jumlah Desa empat belas (14) Desa dan selain daripada jumlah Desa juga terdapat jumlah penduduk secara keseluruhan yang terdata dalam daftar pemilihan tetap mencapai 16.000 jumlah penduduk. Selain daripada jumlah penduduk, memiliki hamparan pantai yang cukup panjang dari ujung Barat perbatasan dengan Kecamatan Ambalawi, pemekaran dari Kecamatan Wera, dan sebelam Timur sebelah dengan Kecamatan Sape, samping itu Kecamatan Wera adalah Daerah pegunungan yang biasa gunakan untuk bercocok tanam.

Tradisi masyarakat Wera yang masih pegang teguh terhadap nilai adat istiada, saling tolong menolong, satu sama lain. Masyarakat yang beraktifitas sebagai petani masyarakat Wera dan kebanyakan masyarakatnya adalah petani, di lihat dari adanya pertumbuhan masyarakat ada juga yang petani bawang merah, kacang, kedalai, dan ini membuktikan bahwa di Kecamatan Wera memiliki banyak sumber daya alam. selain dari pertanian pertenakan juga merupakan bidang kedua terbanyak yang di lakoni masyarakat wera karena daerah ini memiliki lahang untuk peternakan cukup memadai, banyak lahang yang belum dipergunakan untuk yang lain digunakan, sebagai lahang peternakan, ternak yang biasa dilakukan oleh masyarakat tersebut, adalah kerbau, sapi, kuda, dan lahang ternak berada di Desa Oi Tui dan Payi. selain masyarakat yang beraktifitas sebagai petani dan peternakan, namun ada juga masyrakat yang beraktifitas di laut dan juga menjadi pekerjaan yang sebagian masyarakat dan dengan luas lautan yang dimiliki oleh masyarakat Wera.

Hal lain potensi potensi pertambangan juga menjadi faktor yang melimpah di baik persoalan pertambangan emas dan juga pasir basir, uranium, pada sisi pemanfaatan sumber daya alam yang tidak maksimal sehingga banyak masyarakat di rugikan dalam proses 
apapun, seharus pemerintah daerah memberikan ruang dengan regulasi yang tepat dalam mengelola semua potensi yang ada. Persoalan yang krusial adalah pertambangan pasir besir kelolah oleh Pt Jaga Mahase. Moh. Mahfud MD, (2011) mengatakan bahwa "aspek pembangunan yang harus dipadukan sangat penting jika di bangun dengan regulasi lingkungan hidup yang ketat dan kuat dalam pembangunan hukum". Hal yang juga harus dipadukan di dalam pembangunan hukum Indonesia adalah hubungan antara hukum dan masyarakat, yakni pemaduan antara hukum sebagai alat perubahan masyarakat dan hukum sebagai cermin keadaan masyarakat.

Ketika pemerintah memberikan ijin pertambangan pasir basi di Kecamatan Wera Pada tahun 2004 yang di kelola oleh PT. Jagad Mahesa Karya mengajukan surat permohonan izin eksploitasi pertambangan pasir besi. Pemerintah memberikan izin dengan instrumen SK 406/2004 tanggal 7 Oktober 2004. Untuk mengelola pertambangan pasir besi di Kecamatan Wera dan Kecamatan Ambalawi. Setiap pembangunan tentu akan ada analisis dampak lingkungan (AMDAL), karena untuk menjawab persoalan yang akan datang. Kita tau bahwa pertambangan yang ada di Indonesia pada umumya yang menjadi persoalan utama adalah analisis mengenai dampak ligkungan (AMDAL) misalnya Lumpur Lampindo di Sidiarjo, sampai hari ini persoalan tersebut telah memberikan efek negatif kepada masyarakat setempat.

Riyadi dkk (2005) kegiatan galian tambang Analisis mengenai dampak lingkungan hidup, yang selanjutnya disebut (AMDAL), adalah kajian mengenai dampak penting suatu usaha pertambangan yang direncanakan pada lingkungan hidup yang diperlukan bagi proses pengambilan keputusan tentang penyelenggaraan usaha, kegiatan. izin usaha pertambangan adalah izin yang diterbitkan oleh instansi teknis untuk melakukan usaha pertambangan. Kerusakan lingkungan adalah degradasi lahan yang besar, yang apabila tidak ditanggulangi secara cepat dan tepat akan menjadi lahan kritis sampai akhirnya menjadi gurun. Ton Dietz, (1998) mengatakan Persekutuan-persekutuan politik yang aneh sengaja di kaburkan yang antara lain ditemukan adanya lembaga donor asing yang bekerjasama dengan para politisi etnis setempat agenda-agenda lingkungan mereka malah membenarkan pembunuhan sebagai cara untuk mencapai tujuan-tujuan mereka sendiri yang lebih meragukan.

Ada kebuntuan komunikasi antara masyarakat, Pemerintah dan Perusahan yang tidak memenuhi unsur transaksi kebutuhan salah satunya kebutuhan masyarakat yang tidak banyak di berikan oleh perusahan. Sehingga pada tahun 2008. Pemuda menilai bahwa kehadiran pertambangan hanya membawa kemiskinan dan bencana lingkungan hidup. Maka masyarakat dan pemuda membentuk lembaga takti sebagai lembaga penyatuan tujuan untuk menolak pertambangan. Sepanjang kehadiran pertambangan di Kecamatan Wera tidak banyak masyarakat yang mendapatkan kenikmatan kesejahteran baik melalui bantuan pendidikan, kesehatan, dan tenaga kerja. Gerakan yang di bangun pada tahun 2008 dengan melakukan aksi di kantor Bupati Bima selama dua hari dan hasil dari tuntutan pemerintah memberhentikan untuk sementara waktu namun proses eksploitasi pertambangan pasir besi di Kecamatan Wera Desa Oi Tui pada tahun 2009. Ketidak puasnya masyaakat yang tinggal di sekitar pertambangan mulai mulai melakukan perlawanan dengan mengusir perushaan pertambangan yang sedang operasi di wilayah Kecamatan Wera. Tangan besi pun di gunakan oleh yaitu aparat keamanan yang di manfaatkan untuk mengamankan lokasi pertambangan dan akhirnya terjadi bentrok dengan aparat keamanan.

Maka dalam hal ini perlu di lakukan penelitian terkait dengan persoalan di atas. Dalam hal mengambil "Judul Gerakan Penolakan Masyarakat terhadap pertambangan pasir besi di Kecamatan Wera Kabupaten Bima". Menjadi fokus penelitian ini terkait dengan perlawanan masyarakat terhadap pertambangan. yang kemudian pola kerja sama dan pemanfaatan terhadap sumber daya alam. Penyajian dan pembahasan penelitian ini dimulai dengan mengambarkan model gerakan masyarakat, dan pola kerja 
sama Pemerintah Daerah, Pemerintah, pelaku usaha. Serta bentuk pengawasan dan pengelolaan sumber daya alam. Berbagai aspek yang berkaitan untuk menunjukan bahwa pengawasan dan pengelolaan pertambangan pasir besi yang meliputi masyarakat, kepedulian pengusaha, konsistenya Pemerintah dalam memberlakukan aturan.

\section{METODE PENELITIAN}

Penelitian ini menggunakan pendekatan kualitatif . Pendekatan kualitatif yang digunakan sifatnya deskriptif. Lokasi penelitian ini dipilih di Desa Oi Tui Kecamatan Wera Kabupaten Bima. Lofland, dalam Lexi J. Moleong (2002) sumber data utama dalam penelitian kualitatif ialah katakata dan tindakan, selebihnya adalah data tambahan seperti dokumen dan lain-lain. Sumber data untuk menjawab pola kerja pemerintah daerah, pelaku usaha dan masyarakat dalam pemanfaatan sumber daya alam adalah hasil wawancara, analisis dokumen berupa peraturan daerah. Teknik pengumpulan data yang dilakukan melalui, Observasi, Wawancara, Dokumentasi.

Dalam Pikiran Yanuar, Ikbal. (2012). Pemeriksaan keabsahan data dalam penelitian kualitatif meliputi teknik: 1) uji Kredibilitas; 2) uji Transferabilitas; 3) uji Konfirmabilita, dan 4) uji dependabilitas. Teknik analisa data kalau pikiran Miles dan Haberman yang dikutip dalam Sugiyono, (2011) dengan secara interaktif melalui proses data reduksi, Displai Data, verifikasi data.

\section{HASIL DAN PEMBAHASAN}

Peneliti ikut melibatkan beberapa hasil penelitian yang dilakukan secara akademi oleh para ilmuan yang ikut melibatkan dari dalam penelitian sosial ataupun persoalan konflik pertambanga pada umumnya yang terjadi di Indonesia. Dalam hal ini penulis berusahan memilik penelitian terdahulu yang berkaitan dengan pertambangan pasir besi. Adapun hasil dari kajian tersebut yang peneliti anggap cukup keterkaitan meskipun tidak secara tegas mengkajinya tentang resistensi masyarakat akan tetapi pada bidang ilmu pengetahuan sama. Dalam jurnal yang telah dipublikasikan Eka Zuni Lusi Astuti dengan judul Konflik Pasir Besi: Pro dan Kontra Rencana Penambangan Pasir Besi di Kabupaten Kulon Progo Eka Zuni, Lusi Astuti, (2012).

Hasil karya ilmiah tesis Inarni Nur Dyahwanti, yang telah dipublikasikan dalam bentuk jurnal dengan judul kajian dampak lingkungan kegiatan penambangan pasir pada daerah sabuk hijau gunung sumbing di kabupaten temanggung, Inarni Nur Dyahwanti, (2007). Terkait dengan beberapa penelitian terdahulu yang menjadi acuan dalam penulisan. Dengan melihat beberapa penelitian terdahulu seperti yang penelitian dilakukan oleh Eka Zuni, Lusi Astuti, pro dan kontra antar masyarakat tentang pertambangan pasir besi. Maka penulis tidak aka sama dengan persoalan yang dibahas oleh peneliti sebelumnya, penelitian ini lebih pada penekannya tentang perlawanan masyarakat dan pola kerja sama antar Pemerintah dan pengusaha dalam mengelola sumber daya yang disebut pasir besi. Tony Djogo, Dkk (2003) Mengatakan bahwa kebijakan dan kelembagaan sulit dipisahkan, seperti dua sisi sekeping mata uang. Kebijakan yang bagus tetapi dilandasi kelembagaan yang jelek tidak akan membawa proses pembangunan mencapai hasil secara maksimal. Demikian juga sebaliknya, kelembagaan yang bagus tetapi kebijakannya tidak mendukung juga membuat tujuan pembangunan sulit dicapai sesuai harapan.

Maka dalam hal ini, layak untuk mendiskusikan pandangan-pandangan tentang perlawanan masyarakat kelompok subordinat. Tentu saja, salah satu tokoh yang sangat menonjol di sini adalah James C. Scott. Melalui beberapa tulisanya, dia melakaukan elaborasi yang cukup kritis atau praktekprakter perlawanan marjinal. Scott (1990) mengatakan dengan menggambarkan praktek perlawanan kelompok subordinat ibarat oposisi seorang editor surat kabar yang bekerja di bawah sensor yang ketat dari atasannya. Posisinya yang lemah membuat dia harus berlaku sedemikian rupa sehingga ia tetap bisa menyampaikan pesan. Ini membutuhkan satu semangat eksperimental dan kapasitas untuk menguji dan 
mengeksploitasi semua celah, ambiguitas, ketenangan, dan perilaku yang ada. Ini berati harus mempertimbangkan berbagai ukuran yang digunakan oleh pemegang otoritas tentang hal yang dibolehkan dan dilarang.

Lanjut Scott mendefinisikan resistensi (kelas) diproduksi dalam konteks perlawanan kelas petani bawah sebagai kelas subordinat dalam menghadapi kekuasaan dan atau tua tanah yang dianggap memiliki kekuatan, sehingga dapat mengambik kebijakan pembangunan negara. Dalam konteks budaya secara umum, jenis resistensi ini lebih bermakna sebagai siasat atau takti dalam menghadapi kultur dominan. Tourine (1985) mengatakan bahwa gerakan sosial merupakan interaksi yang berorientasi normatif antara lawan atau saingan beserta penafsiran yang sarat konflik dengan modal masyarakat yang berlawanan dari sebuah medan budaya bersama. Rumusan gerakan sosial Tourine ini tidak luput dari model identitas murni yang dikembangkannya.

\section{Hasil Penelitian}

Pada awal gerakan penolakan tersebut, karena berdasarkan analisis dari berbagai kalangan pemuda Wera yang kuliah di berbagai daerah yang ada di Indonesia, ada yang dari Makasar, dari Mataram, Jakarta. Kemudian pulang mahasiswa sehingga melakukan propaganda kepada masyarakat, bahwa pertambangan akan merusak lingkungan, serta kehidupan masyarakat tidak akan nyaman disebabkan adanya perusahan pertambangan. Selain dari pada itu propaganda mahasiswa pun melakukan dengan memutar film tentang pertambangan yang ada di Indonesia. Bahwa pertambangan yang ada hanya membawa penyakit bagi masyarakat, dan tidak ada jaminan yang nyata, yang bisa dipercaya oleh masyarakat, semua ungkapan dari perusahan hanya ungkapan palsu.

Seiring berjalan waktu dengan propaganda yang dilakukan oleh mahasiswa, reaksi warga pun mulai muncul dan mulai bertanya tentang, apa benar tambang akan menghancurkan lingkungan atau tidak. Namun dominasi pemikiran dari mahasiswa tersebut sehingga pandangan masyarakat tentang pertambangan adalah penyakit bagi kehidupan dan lingkungan. Sisi lain daripada masyarakat yang biasa hidup dengan aktifitas nelayan dan petani tentu sulit untuk menerima kehadiran pertambangan, apalagi pertambangan hadir sebagai siluman. Ketika pertambangan masuk secara tiba-tiba tanpa melakukan sosialisasi yang jelas, sudah pasti akan menimbulkan reaksi masyarakat di beberapa Desa di Kecamatan Wera.

Selain memberikan pemahaman masyarakat, mahasiswa pun mendirikan kelompok-kelompok yang menolak pertambangan, yang sepaham dengan masyarakat, dengan simbol gerakan bahwa pertambangan harus di tolak dan harga mati. Hal tersebut sering bergulir isu-isu perlawanan dari masyarakat dan mulai mengusir pihak Perusahan, karena masuk PT. Jagad Mahesa Karya, yang mengelola Pertambangan pasir besi Kecamatan Wera pada tahun 2008 mulai proses eksploitasinya, di saat kepemimpinan Bupati yang baru yang bernama H. Fery Julkarnaim,St.

Sesungguhnya Pemerintah tidak seharusnya memberikan izin eksploitasi. Yang paling utama adalah izin eksplorasi, supaya pihak perusahan membentuk tim untuk melakukan penelitian terkait dengan kandungan pasir besi, apakah pasir besi layak atau tidak. Pada kenyataan yang terjadi pihak pemerintah mengelurkan izin berdasarkan kepentingan semata tanpa melihat kondisi alam dan kondisi masyarakat.

Hal tersebut akan menimbulkan, perlawanan masyarakat ketikan melihat proses tersebut, karena disebakan oleh suatu tindakan Pemerintahan dan pihak perusahan yang tidak sesuai dengan keinginan masyarakat pada umumnya yang ada di Kecamatan Wera Kabupaten Bima. Perlawanan muncul ketika masyarakat yang hidup pinggir pantai seperti, Desa O'i Tui,Dusun Radu Desa Bala, Desa Pai, Desa Kala Jena. Ketika temui salah seorang pemuda yang tinggal di Desa Bala Kecamatan Wera. Sebagai pelopor gerakan mahasiswa yang menolak pertambangan pasir besi di Kecamatan. Pemuda yang tidak terlalu banyak bicara dan juga tidak terlalu banyak bercanda.

Salah seorang tokoh pemuda yang tinggal di Desa Rangga Solo Kecamatan 
Wera, yang inisial (FM), 37 tahun, yang berperofesi sebagai wira usaha, mengatakan. "Awal masuknya pertambangan pasir besi di Kecamatan Wera Kabupaten Bima pada tahun 2004 dan dengan istrumen surat keputusan Sk 406 dan 407 dan surat keputusan tersebut di keluarkan pada masa pemerintahan Drs. Jainul Arifin, M.Si selaku Bupati Bima pada 2004. Dengan sehingga membuat satu perjanjian bahwa seluruh masyarakat di pinggir pantai di berikan peluang untuk bekerja di wilayah pertambangan. Namun kenyataan di lapangan tidak seperti yang direncanakan awalnya. (Wawancara Pada Hari 28 Juli 2015 Di Desa Rangga Solo).

Bahwa pernyataan informen di atas, Pemerintah dan pihak Perusahan telah memberikan perjanjian kepada masyarakat setempat, akan membuka peluang kerja di dalam perusahan pertambangan pasir besi tersebut untuk mengatasi kemiskinan dan pengangguran. Namun pada kenyataannya sangat sulit bagi pihak pertambangan untuk menerima semua masyarakat yang bekerja di dalam perusahan tersebut, karena di sebabkan mental dan keahlian yang dimiliki oleh masyarakat tidak punya. James scott, (1990) mengatakan bahwa perlawanan sebagai tindakan yang dilakukan oleh kaum atau kelompok subordinat yang ditujukan untuk mengurangi atau menolak klaim yang dibuat oleh pihak atau kelompok superdinat terhadap mereka.

Salah seorang yang bernama (TJ, 38 tahun) di Desa Oi Tui sebagai kepala dusun, dan aktifitas keseharianya sebagai petani dan nelayan, karena pendidikan terakhirnya Tamat Sekolah Menengah Atas (SMA). Ia Mengatakan "Kami melihat kedatangan orang yang mengambil pasir kami langsung ke Kantor Camat agar dapat mengeluarkan mobil pengakut pasir. Kemudian pak Camat datang untuk bernegosiasi dengan pihak Perusahan hasilnya tersebut bahwa alat berat sebagai pengakutan pasir di keluarkan dari tempat tersebut. Selang seminggu pihak perusahan mengundang Pemerintah Kabupaten untuk memberikan sosialisasi kepada kami dan setelah pihak Pemerintah Daerah datang mereka memberikan arahan kepada masyarakat agar menanam sayur sebanyak-banyak, untuk di jual kepada pihak perusahan". (minggu 30 september 2015 di dusun oi Tu'i desa oi Tui).

Kehadirian Pemerintah dan perusahan dalam proses sosialisasi yang lakukan harus memberikan pendidikan secara langsung terhadap masyarakat terkait dengan adanya pertambangan. Bukan pada saat situasi konflik terjadi baru di lakukan sosialisasi dan hal itu memang mustahil bisa di terima oleh masyarakat, karena pahaman masyarakat terhadap pertambangan membawa dampak buruk kehidupan lingkungan dan sosial.

Sinergisitas pikiran DPRD dan Pemda, Perusahan hanya melakukan sosialisasi 1 kali saja dan setelah pihak perusahan langsung melakukan eksploitasi da seharusnya yang di lakukan adalah eksplorasi, karena pertambangan menjadi sesuatu bermasalah jika pihak masyarakat tidak bisa memahami tentang pertambangan dan kalau masyarakat berikan subsidi pikiran yang sehat dan baik tentu mungkin tidak terjadi hal-hal dalam penolakan. Gerakan mahasiswa trus di lakukan baik di lokasi Oi Tui maupun di kantor Camat dan bahkan di Kantor Bupati dengan tunutan meminta Pemerintah agar mencabut ijin pertambangan.

Salah seorang asli Bima orang yang menjabat sebagai Humas di dalam perusahan PT. Jagad Mahesa Karya, yang biasa di sapa dengan (Bimo), nama ini kemungkinan nama samarannya, dan pendidikan sarjana hukum dan di lain hal dia memiliki tanggungan dan beristri. Mengatakan adalah sebagai berikut. "ia ada dua hal yang bisa di lihat, pertama Pertambangan di berhentikan untuk sementara waktu dikarena ada masalah dari Pemerintah Pusat. Kedua Bahwa pihak perusahan memberikan pekerjaan terhadap orang yang ada di lingkar tambang untuk sebagai tenaga kerja". (19 agustus 2018 di kantor perusahan jagad mahesa karya).

Dengan paparan dari bagian humas PT. Jagad Mahesa Karya, bahwa pertambangan telah memberikan kontribusi terhadap masyarakat setempat dengan memberikan pekerjaan terhadap masyarakat setempat yang asli Wera. Analisis dampak lingkungan pernah dirancang oleh Daerah, karena Pemerintah 
yang tidak memahami tentu akan berimplikasi kepada lingkungan hidup. Sisi lain bahwa analisis mengenai dampak lingkungan (AMDAL), dibuat oleh pihak perusahan. Pertambangan pasir besi di Kecamatan Wera Kabupaten Bima melahirkan perlawanan masyarakat, karena dinilai pertambangan tidak mampu memberikan konstribusi nyata bagi kehidupan masyarakat. Resistensi dimungkinan karena dominasi dan hegemoni tidak pernah bisa total.

Sebagaimana yang dinyatakan Butler (1990), bahwa regulasi praktek-praktek identifikasi. Kebijakan Pemerintah Daerah Kabupaten Bima, berawal di keluarkan oleh pemerintah Jainul arifin sebagai Bupati Bima 2004 dengan instrumen surat keputusan (SK) no.406/2004 kepada PT. Jagad Mahesa Karya. Dengan memberikan kuasa pertambangan eksploitasi bahan galian pasir untuk jangka waktu selama 5 tahun berturutturut terhitung mulai tanggal 7 oktober 2004 s/d 7 oktober 2009. Atas lokasi seluas 3.77 Ha. Anthony Oberschall (1973) mengatakan bahanya bisa didapat dari sumber alam, yang kemudian meliputi uang, pendamping organisasi sebagai tenaga kerja untuk menyatukan komunikasi antar kedua belah pihak, karena keputusan dalam sebuah organisasi sebagai komitmen yang dibangun berdasarkan pertimbangan yang legal rasional. Di lain hal bahwa teori mobilisasi sumber lebih pada, memfokuskan perhatiannya kepada proses-proses sosial yang memungkinkan muncul dan berhasilnya suatu pembangunan tergantung kepada kebijakan yang tepat untuk kepentingan publik.

Izin yang dikeluarkan oleh Bupati Bima yaitu H. Fery Julkarnain,St. Pada tahun 2009 sebagai perpanjangan usaha yang di ajukan oleh pihak perusahan. Dengan pemegang izin operasi produksi mempunyai hak untuk melakukan kegiatan konstruksi, produksi, pengangkutan dan penjualan serta pengolahang dan pemurnian dalam wilayah izin usahan pertambangan, untuk jangka waktu 2 tahun mulai tanggal ditetapkanya keputusan sampai dengan tanggal 17 maret 2012. Kalau operasi pertambangan terus menerus, tentu hal ini akan membuat warga tidak nyaman dalam beraktifitas atau mencari nafkah, karena disebakan dengan adanya proses eksploitasi pertambangan. Sementara masyarakat yang tinggal di dalam dataran rendah tentu sumber kehidupanyan adalah petani dan nelayan, dan bearti sumber kehidupan masyarakat tidak bisa lepas dari hal yan biasa dilakukannya.

Ketika Pemerintah mencoba merubah cara pandang masyarakat dari masyarakat agraria menuju masyarakat industri, tentu secara pemahaman masyarakat yang masih kurang. Terkadang izin yang dikeluarkan oleh Pemerintah Daerah tidak berdasarkan aspek kebutuhan masyarakat namun kebanyakan izin yang di keluarkan oleh Pemerintah berdasarkan pada aspek politik. Sehingga apa yang terjadi, antara kebijakan Pemerintah dan keinginan masyarakat tidak sesuai tentu akan melahirkan perlawanan. Tingkat komunikasi Pemerintah terhadap masyarakat tidak maksimal, karena pemerintah menganggap apa yang dilakukannya akan setuju oleh masyarakat, namun pada kenyataan masyarakat juga bisa menganalisa segala sesuatu yang tidak sesuai dengan keinginan.

Singh (2001) mengatakan bahwa sistem mobilisasi yang terorganisir secara rasional. Teori mobilisasi sumberdaya berasumsi bahwa dalam suatu masyarakat dimana muncul ketidakpuasan maka cukup memungkinkan untuk memunculkan sebuah gerakan sosial. Dengan adanya pengajuan perpanjangan kontrak, maka Pemerintah respon dengan memberikan perpanjangan izin kontrak agar perusahan tersebut dapat beroperasi di wilayah wera, dengan instrumen SK (188). Setelah pertambangan melakukan eksploitasi pertambangan pasir di wilayah Desa Oi Tui dan Tawali, masyarakat pun mulai merasakan efek dari kegaiatan pertambangan yaitu efek negatif sebagai berikut:

1. Masyarakat tidak bisa melakukan aktifitas di laut untuk melanjutkan kehidupan mereka setiap hari dalam mencari nafka untuk kebutuhan hidup masyarakat masing-masing.

2. Masyarakat dihantui dengan ancaman bencana lingkungan dan abrasi besar- 
besaran.

Membentuk gerakan sosial sebagai gejala yang alternatif jalan dalam ruang dialektika. Oberschall (1973) mengatakan hubungan sosial telah membentuk hubungan yang kuat sebagai bentuk tindakan bersama, untuk mencapai apa yang diinginkan. Misalnya ketika gerakan perlawanan masyarakat terkait dengan adanya pertambangan pasir besi di Kecamatan tentu Kecamatan lain pun ikut melibatkan sebagai bentuk komitmen bersama berdasarkan persoalan tersebut. Otto Soemarwato ( 2009) mengatakan bahwa Penyebaran AMDAL yang sangat cepat, yang terjadi pada waktu gerakan lingkungan merupakan suatu model yang hangat membawa akibat tidak dikaji dengan saksama apa sebenarnya AMDAL itu. Oleh karena itu banyaklah terjadi kekeliruan dalam pengunaan AMDAL. Di banyak negara, termasuk Indonesia kekeliruan itu menjadi sangat luas, sehinggah dapatlah disebut sebagai salah kaprah.

Peneliti mengurai kembali terkait dengan kebutuhan masyarakat, apakah pihak pertambangan penuhi hak rakyat yag telah di janjikan kepada masyarakat. Dalam hal ini ada beberapa hal sebagai berikut. Perusahaan pertambangan tidak merealisasikan kewajibannya dalam bentuk tanggung jawab sosial perusahaan Corporate social renponsibility (CSR) terhadap masyarakat yang dianggap rugi oleh pihak perusahaan yang harus dipertanggung jawabkan.

Ekspor pertama bahan material yang di lakukan oleh pihak PT. Jagad Mahesa Karya, tambang pasir besi dari Kecamatan Wera ke Negara Cina. Dan lebih kurang 10.000 ton pasir besi yang telah di ekspor, dan itu pengiriman pertaman. Karena sebelum pihak pertambangan memberikan upah kepada masyarakat untuk galian pasir besi secara manual. Dan yang menjadi target pengekspor bahan material tersebut dan terus akan meningkat tiap bulan rencanan.

Kalau ukur dengan ekspor sebesar itu tentu warga akan tidak akan mengalami kemiskinan, lagi kita katakan bahwa pihak perusahan hanya menjadi rakyat sebagai budak di dalam perusahan tersebut. Collins (1975), mengatakan, muncul sesuatu yang tidak baik sebagai bentuk solidaritas. Jika Anda memegang atau percaya pada satu sisi dalam suatu konflik, definisi dari kekejaman akan tampak secara moral benar. Perlawana masyarakat Wera merupakan titik awal dari semua gerakan perlawanan masyarakat yang ada di Bima, terhadap pertambangan, baik itu pertambangan pasir besi atau pun pertambangan lainya.

Adanya lembaga yang di bangun pada saat itu masyarakat, bisa menyatukan pemahaman dalam mengawal kasus tersebut. Karena semua masyarakat yang tergabung dalam gerakan tersebut tentu orang-orang yang memiliki kesamaan ideologi. Selama gerakan penolakan pertambangan tersebut, masyarakat menduduki Kantor Bupati Bima selama tiga hari, hingga akhir Pemerintah menerima tuntutan masyarakat bahwa pertambangan akan di mencabut untuk sementara waktu.

Tahapan kedua gerakan masyarakat dan represif pihak keamanan, tersebut merupakan proses kembali pihak perusahan dalam melakukan eksploitasi pertambangan pasir di Kecamatan Wera, di masa itu mahasiswa dan pemuda serta masyarakat kembali mendirikan lembaga takti grakan dengan nama lembaga tersebut Fron Gerakan Rakyat Anti tambang (FGR), pola gerakan pada tahun 2009 masyarakat tidak lagi menuntut Bupati Bima, tetapi pola gerakan masyarakat langsung menyerang base camp pertambangan, sampai masyarakat dan pihak pertambangan serta aparat keamana, saling kerja mengejar di laut. Pada saat pertambangan lagi mengangkut pasir besi di sekitar wilayah Radu Desa Bala, masyarakat langsung melakukan pengusiran terhadap pihak pertambangan, sehingga di dalam gerakan tersebut masyarakat ada yang di tangkap lebih kurang 10 orang, serta lukaluka akibat tindakan aparat kepolisian, yang tidak memiliki hati nurani.

Dengan memperhatikan resistensi yang dilakukan oleh masyarakat merupakan akibat-akibat yang mungkin terjadi, sebaliknya dengan tujuan mereka hampir selalu kesempatan hidup dan ketekunan Scott (1990). Masyarakat melakukan gerakan, karena sudah merasakan efeknya negatif dari 
pertambangan pasir besi. Masyarakat menilai bahwa pertambangan hanya membawa bencana bagi kehidupan masyarakat serta bagi para binatang, yang menetap di Kecamatan Wera, serta ikan yang ada di lautpun merasakan efek pertambangan.

Tahapan ketiga Gerakan pada tahun 2011, masyarakat kembali di kagetkan dengan kedatangan kapal perusahan yang muatan lebih dari ribuan ton, dalam dugaan tersebut masyarakat kembali bertanya apakah pertambangan masih melakukan operasi atau tidak, semua unsur yang terlibat dalam persoalan pertambangan diam semua dan tidak ada yang berani angkat bicara. Di lain pihak sebagian kelompok pemuda mengatakan bahwa pertambangan tidak lagi melakukakn operasi berdasarkan tindakan tersebut selama empat bulan tidak melakukan operasi atau aktifitas secara manual.

Faktanya, bahwa kehadiran kapal yang mengangkut bahan material membukti bahwa pertambangan masih melakukan operasi dan itu menjadi sesuatu hal yang sangat jelas. Lain hal pihak perusahan dan Pemerintah menggunakan jasa keamanan untuk menjaga lokasi pertambangan pasir besi yang ada di Kecamatan Wera. Masyarakat pun tidak terlalu berani mendekati lokasi pertambangan pasir besi. Dengan masuk lagi pertambangan pasir besi di Kecamatan Wera mahasiswa yang kuliah di luar Bima melakukan aksi penolakan terhadap tambang dari berbagai daerah ikut mereaksi terhadap adanya pertambangan, karena mahasiswa melihat pertambangan yang ada di Indonesia tak ubahnya dengan monster yang menakuti masyarakat di setiap saat dan itu menjadi penyakit kalau pertambangan di biarkan secara begitu.

\section{Kesimpulan}

Penelitian dapat di tarik kesimpulan bahwa kehadiran pertambangan di Kecamatan Wera . Model gerakan resistensi masyarakat, ada beberapa faktor yang mendasari penolakan masyarakat.

1. tidak ada sosialisasi yang dilakukan oleh Pemerintah kepada masyarakat Kecamatan Wera Kabupaten Bima terkait dengan masuk perusahan Jagad Mahesa Karya, yang bergerak dibidang pertambangan pasir.

2. Kedua Pertambangan pasir besi yang ada di Kecamatan Wera belum bisa diterima oleh masyarakat, karena pemahaman masyarakat terhadap pertambangan masih kuramng.

3. Selama adanya pertambangan tidak ada hal yang bisa di manfatkan oleh masyarakat setempat baik melalui kesehatan pendidikan, dan tenaga kerja.

4. Pertambangan di kecamatan Wera perlu adanya rekosuliasi antara masyarakat, Pemda dan pelaku usaha.

\section{Daftar Pustaka}

Anthony, Oberschall. 1973. New Social Movement Theory and Resource Mobilization Theory: The Need for Integration.

Collins, R. 1975. Conflict sociology. New York: Academic Press.

Eka Zuni, Lusi Astuti. 2012. Konflik Pasir Besi: Pro dan Kontra Rencana Penambangan Pasir Besi di Kabupaten Kulon Progo. Jurnal Ilmu Sosial dan Ilmu Politik.Volume 16, Nomor 1, Juli (62-74) ISSN 1410-4946.

Inarni Nur Dyahwanti. 2007. kajian dampak lingkungan kegiatan penambangan pasir pada daerah sabuk hijau gunung sumbing di kabupaten temanggung. Universitas diponegoro semarang. Akses pada hari rabu agustus tahun 2015.

James C. Scott. 1990. Deconstructing Equlity versus Difference'in Hirssd and Fox keller (eds) konflict in feminism. London and new york: Routledge.

Lexi J. Moleong 2002. Metologi Penelitian Kualitatif.Bandung : PT. Remaja Rosda karya.

Mahfud MD. 2011. Membangun Politik Hukum, Menegakkan Konstitusi. Jakarta: PT Raja Grafindo Pertsada.

Mardiasmo. 2002. Akuntansi sektor publik. Edisi pertama. Yogyakarta. Andi

Otto Soemarwoto. 2009. Analisis Mengenai Dampak Lingkungan.Yogyakarta: Gajamada University. 
Otto Soemarwoto. 2009. Analisis Mengenai Dampak Lingkungan.Yogyakarta: Gajamada University.

Riyadi,.dkk. 2005. Perencanaan Pembangunan Daerah. Jakarta : PT Gramedia Pustaka Utama.

singh, Rajendra. 2001. Social Movements, Old and New: A PostModernist Critique, New Delhi/Thousand Oaks/London: Sage Publications.

Sugiyono. 2011. Metode penelitian kuantitatif kualitatif dan R\&D. Bandung: Alfabeta.

Ton Dietz. 1998. Kontur Geografi Lingkungan Politik. Pengakuan Hak Atas Sumber daya Alam.kerjasama. Pustaka pelajar. jogja: INSIST Pres dan REMDEC.

Tony Djogo,. Dkk. 2003. Kelembagaan Dan Kebijakan Dalam Pengembangan. agroforestri w o r ld agr ofo res tr y centr e (ICR AF).

Touraine, A. 1985. Sosial Movement and Sosial Change. Orlando Fals Bonda (ed.) The Challenge of Sosial Change. (London: Sage)

Yanuar, Ikbal. 2012. Metode Penelitian Sosial Kualitatif. Bandung: Reifika Aditama. 